\title{
Moving Across, Looking Beyond
}

\section{Rachel Standfield}

Mobility has become one of the key themes of new imperial history writing as scholars trace the movement of people, things and ideas across imperial spaces and national boundaries, exploring the networks that lay at the heart of imperial endeavour. Developing out of attempts to unsettle and destabilise the connection between the nation and historical scholarship from the mid-twentieth century, histories of mobility have brought a focus on the 'transnational realities' that 'threaten to weaken the hegemonic claim of the nation'. ${ }^{1}$ Recognising that histories of the nation tend to focus on what is distinctive rather than what is shared, ${ }^{2}$ historians of British imperialism have turned the gaze back upon what is held in common in imperial spaces. Building on metaphors of British imperialism as networked - such as the webs of empire theorised by Tony Ballantyne or the view of imperial networks espoused by Alan Lesterimperial histories of mobility have given scholars the freedom to trace the paths by which people, goods and ideas have been disseminated throughout the British imperial world. ${ }^{3}$ Following the tracks of mobile lives provides a means of tracing connections between disparate imperial sites and understanding the particular local circumstances of varied

\footnotetext{
Byrnes 2009: 126.

Curthoys 2003: 84.

3 Ballantyne 2002; Lester 2001.
} 
colonial locations, while managing the complex scholarship of multiple historiographies and dispersed archives that can make transnational histories so challenging. ${ }^{4}$

There have been significant developments in scholarship in the area of histories of mobilities. Numerous scholars have examined the travels of Europeans and the meanings of mobility for European people and settler colonists, but the mobility of Indigenous peoples has received less attention. ${ }^{5}$ Historians of Indigenous life and colonisation have begun to rectify this gap in scholarship by exploring the patterns of Indigenous mobility. There is a small but growing body of work that engages with the mobile Indigenous subject in imperial and colonial historical contexts. This scholarship responds to Tony Ballantyne and Antoinette Burton's claim, in Moving Subjects, that work on mobility in general, and intimate cross-cultural encounters in particular, by depicting Europeans as global subjects, has rendered Indigenous people as purely 'local' in contrast to the figure of the mobile European. In much historical scholarship, 'mobility becomes the property of colonizers, and stasis the preternatural condition of the indigene', yet, as discussed below, in Australia, Indigenous movement was central to colonial discourses that denied land rights and led to colonial policies to 'settle' populations. ${ }^{6}$ Alan Lester and Zoe Laidlaw contend that 'Western agents and networks are often seen as global and mobile', whereas 'indigeneity is too frequently defined as local and static, leaving the problem of where and how Indigenous people connect with trans-global networks ill-defined'.7 Jane Carey and Jane Lydon, in Indigenous Networks: Mobility, Connections and Exchange, posited that 'stereotypically, Indigenous people are seen as either autochthonous and fixed, or as displaced and inauthentic'. ${ }^{8}$ Ballantyne and Burton contended that one effect of the binary between the mobile European subject and the fixed Indigenous subject is that 'the agency of the Indigenous subject ... is rarely apprehended, let along recognized, as a subject of historical inquiry in its own right'.?

$4 \quad$ Lambert and Lester 2006.

5 See, for example, Russell, Deacon and Woollacott 2008; Deacon, Russell and Woollacott 2010;

Curthoys and Lake 2005.

6 Ballantyne and Burton 2009: 5.

7 Lester and Laidlaw 2015: 6.

8 Carey and Lydon 2014: 1.

9 Ballantyne and Burton 2009: 6. 
This collection aims to contribute to this emerging body of work, recognising Indigenous people as subjects in their own right by exploring Aboriginal and Māori movement in the nineteenth century. Authors in this collection examine the ways that Indigenous people moved, their motivations for doing so, and the ways that travel affected the travellers, other members of their communities and the non-Indigenous people they encountered. Chapters consider the cultural aspects of travel for Indigenous communities on both sides of the Tasman, exploring motivations for both individuals and communities to travel, and looking at the effect that Indigenous travel had on Indigenous individuals, Indigenous communities and non-Indigenous people. Authors here insist that Indigenous mobility in imperial and colonial contexts must be considered an extension of pre-colonial travel, embodying Indigenous values and community-specific motivations for travel. Setting out this context helps to draw out the Indigenous-specific experience of travel when looking at imperial and colonial contexts, which helps to challenge the assumption that Indigenous people were merely engaged in travel for European purposes or along European lines. By understanding the context of pre-colonial Indigenous mobility, we can focus on Indigenous mobility in imperial and colonial contexts, seeing it as more than simply travelling or working with Europeans.

In keeping with the geographical locations of the authors, the work follows an antipodean theme, considering Māori and Aboriginal mobility in imperial and colonial contexts. This introduction sets out the broad contours of Indigenous Australian and Māori travel, engaging with mobility in both pre-colonial and colonial contexts, and considering the meanings accorded mobility in colonial contexts on opposite sides of the Tasman. As well as investigating the movement of Indigenous people across national borders, the chapters investigate Indigenous mobility within settler colonies and nations, recognising the importance of Indigenous people travelling to other Indigenous communities, across iwi, nation or language group borders, as a cross-cultural encounter. The contributors-scholars in Indigenous studies, historians of Indigenous societies and Indigenous academics-share interests in the intersections of Indigenous cultures and history, and ongoing implications of colonisation for Indigenous communities in Australia and New Zealand, and they bring these interests to bear on the history of mobility. 
Although the field of research is small, several pivotal studies of mobile Indigenous subjects in imperial and colonial historical contexts have laid the groundwork for this collection. In a study of nineteenth-century humanitarian networks, Elizabeth Elbourne recognised the omission of Indigenous people from the significant body of work on the movement of humanitarian discourses, and humanitarians themselves. Existing work gave 'relatively little attention' to the interactions of Indigenous people with the British or with other Indigenous groups, Elbourne argued. Her analysis showed a range of connections between Indigenous groups and people who travelled to England via British humanitarian networks. Significantly, she noted that British imperial networks 'not only contributed to the creation of British policy towards Indigenous people, but also involved Indigenous people directly'. ${ }^{10}$ Further, Elbourne argued that 'imperial networks ... affected Indigenous interlocutors themselves'. ${ }^{11}$ Building on this argument, we maintain that Indigenous people were not only affected themselves, they also affected the Europeans they encountered through humanitarian networks or other types of connections. Authors in this volume seek to recover the ways in which Indigenous people affected mobility, such as through being involved in its creation, shaping its operations, making use of networks for their own ends and travelling for the sake of travel. Special attention is paid to cases that demonstrate Indigenous agency-that is, cases in which Indigenous people chose to engage with or to ignore (or even to shun) connections with Europeans.

Lynette Russell's recent monograph, Roving Mariners: Australian Aboriginal Whalers and Sealers in the Southern Oceans, 1790-1870, detailed the mobile lives of Tasmanian Aboriginal men and women in the whaling and sealing industries. ${ }^{12}$ This followed earlier research into the trans-Tasman career of Tommy Chasland or Chasling, an Aboriginal man who made his home in the mixed Māori and Pākehā sealing and whaling communities of southern New Zealand. ${ }^{13}$ Russell argued that mobility allowed Aboriginal people to 'create a space' for themselves, despite dispossession and colonial intervention. ${ }^{14}$ She documented the 'attenuated agency' that Aboriginal people could (and did) exert through

10 Elbourne 2005: 62.

11 Elbourne 2005: 59.

12 Russell 2012.

13 Russell 2008.

14 Russell 2012: 4. 
their mobility; she neither assumed that Indigenous people were unfettered agents, nor that their interactions with colonial systems rendered them powerless. ${ }^{15}$

Māori mobility in the early decades of the nineteenth century is well documented in the New Zealand historiography, and is thus well known. The work of Anne Salmond, Judith Binney, Alison Jones and Kuni Jenkins, and Ballantyne has illuminated the international journeys of a cohort of Māori, predominantly chiefs and young men, and one young woman, Atahoe. ${ }^{16}$ The journeys to Australia and beyond by Tuki, Huru, Te Pahi, Ruatara and Hongi Hika are familiar to readers, so much so that the journeys made by this group of men from the north of the North Island have, in many respects, come to overshadow other journeys, such as those made by Māori within the New Zealand archipelago; the overseas journeys of Mãori from other parts of the country; and the less frequent, but no less remarkable, journeys of Māori women. Moreover, as several of the chapters in this collection argue, there is relatively little attention paid to how these journeys affected the nature of relationships forged with Europeans or communities at home.

The mobility of people and ideas in Indigenous protest movements has captured the attention of historians. In the Australian context, John Maynard has investigated the impact of mobile black maritime workers on the development of Aboriginal political activism in the early twentieth century. ${ }^{17}$ Ravi de Costa, in his work on international Indigenous politics, represented Indigenous transnationalism as an extension of pre-existing Indigenous 'norms about access to resources, diplomacy and mobility across others' territories, in trade and the sharing of culture'. ${ }^{18}$ Such insights are carried through into chapters in this volume that consider the crossing of borders of Indigenous nations (i.e. movement across Indigenous lands within individual countries) to be as central to Indigenous mobility as travel overseas. Chapters here also take seriously de Costa's emphasis on mobility as a 'norm'. Insights offered by Pacific Studies scholarship, especially the work of Epeli Hau'ofa, likewise play a major role. Hau'ofa's seminal research on the importance of movement

15 Russell 2012: 12-13.

16 Salmond 1997; Binney 2004; Jones and Jenkins 2011; Ballantyne 2014.

17 Maynard 2005.

18 de Costa 2006: 5. 
to Pacific Island cultures and lives shapes our approach to mobility, not as an exceptional occurrence, but as an outcome of culture, economics and social organisation. ${ }^{19}$

Fiona Paisley's work on Māori and Pākehā women's international travel associated with political activism in the twentieth century has made a significant contribution to our understanding of the role of gender in shaping Indigenous mobility. ${ }^{20}$ While considerable attention has been paid to the movement of white women in histories of mobility, ${ }^{21}$ building on Paisley's work, authors in this volume attempt to account for the gendered nature of Indigenous movement and the complexities of uncovering the travel of Indigenous women who are often rendered anonymous in the colonial archive. Paisley's recent monograph, The Lone Protestor, explored the travel of Aboriginal activist A.M. Fernando, a largely unknown campaigner working in the UK and Europe during the inter-war years. As well as bringing Fernando's work into the historical record, Paisley's arguments about his mobility-that it placed him outside national history writing and affected his politics and activism-have changed the way we think about mobility. According to Paisley, Fernando's activism was overlooked by Australian historians because his mobility made him appear peripheral to a nationally focused story. ${ }^{22}$ Fernando linked racism in Australia to the prejudice he witnessed and was subject to in England; thus, he came to understand racism as 'transnational in context, inflamed by the colonial world order and by poverty and ignorance. ${ }^{23}$

In Indians in Unexpected Places, Philip J. Deloria undermined dominant depictions of American Indian people as outside of modernity. His work, which examined the transformed mobility of Indian people through their early embrace of travel via the automobile, played an important role in this developing field. Departing from the more usual focus on international travel within studies of twentieth-century Indigenous mobility, Deloria examined the 'local embrace of the automobile', exploring how this allowed Indian communities to travel within 'Indian country itself'. ${ }^{24}$ In a similar

19 Hau'ofa 1993.

20 Paisley 2006; Paisley 2004.

21 See, for example, chapters in Russell, Deacon and Woollacott 2010; Georgine Clarsen's work has been instrumental in Australian histories of mobility in general and gender in particular. See Clarsen 2008 and 2011.

22 Paisley 2012: xiii, xv.

23 Paisley 2012: xiv-xv.

24 Deloria 2004. 
fashion, Heather Goodall and Alison Cadzow traced Aboriginal mobility on, and relationships to, the Georges River in Sydney. In tracing mobility from pre-European contact to contemporary communities, Goodall and Cadzow showed the connectedness, as well as the 'resilience', of Aboriginal people who were 'sometimes moving ... and sometimes staying tenaciously in one space'. ${ }^{25}$ Taking inspiration from this work, chapters in this volume explore the ways that Indigenous people forged newand continued old-tracks of mobility that maintained connection to traditional country and opened up new places of connection. Goodall and Cadzow's work speaks to the strength and length of connections forged through mobile Indigenous people, and how movement over country continues despite colonisation for Aboriginal people in Sydney (even though it is mostly unknown and unrecognised by the non-Indigenous community, which has built cities over the top of country in its attempt to displace Indigenous people).

Attempting to move away from the more usual focus on IndigenousEuropean connection, other developments in scholarship have looked at the connections formed between different communities of Indigenous peoples via travel. Lachy Paterson examined the participation of Māori in Australian federation in 1901, focusing on meetings between Aboriginal warriors, Māori chiefs and Indian troops jointly assembled for events celebrating the establishment of the Australian nation. ${ }^{26}$ Tracey Banivanua Mar's exploratory study of the 'parallel Indigenous discourses' of anticolonial protest operating in Port Phillip, New Zealand and Tahiti in the 1830s and 1840s emphasised the 'fleeting and ephemeral circuitry' of connection between Indigenous peoples. ${ }^{27}$ Seeking to restore Indigenous peoples in Papua New Guinea and the Torres Strait from the 'margins of international affairs to the centre', Frank David, Leah Lui-Chivize and Jude Philip followed the interconnected lives of three Indigenous men as they travelled through the Torres Strait seascape yabugud (road). Their apparent 'constancy and consistency ... across the fields of commerce, science and religion' allowed 'for consideration of the politics of how these people manipulated events towards their own goals'. ${ }^{28}$ Other work decentres European understandings of mobility by placing it alongside Indigenous and immigrant conceptions, analysing it as simply another

25 Goodall and Cadzow 2009: 25.

26 Paterson 2013.

27 Banivanua Mar 2013: 3-4.

28 David, Lui-Chivizhe and Philip 2015: 290-91. 
in a constellation of meanings associated with travel. Samia Khatun, for example, focused on the various 'tracks' that 'structured mobility through Beltana' on the country of Kuyani people in northern South Australia, where tracks of story from different epistemological traditions created geographies and mobilities across the Australian landscape. ${ }^{29}$

Among recent work, Jane Lydon and Jane Carey's edited collection stands out. It brings together some of the most innovative and thoughtful scholars of new imperial history to recognise Indigenous participation in 'global networks of power and mobility. ${ }^{30}$ In his review of the collection, Michael McDonnell argued that it 'issued a challenge to imperial and transnational historians to start taking seriously Indigenous peoples as dynamic and mobile historical actors' ${ }^{31}$ This challenge motivates the authors in this volume. Carey and Lydon noted, insightfully, that while anthropologists and archaeologists have documented particular forms and meanings associated with Indigenous mobility, historians have not generally incorporated this into their work. ${ }^{32}$ However, even with this recognition, most of the essays in Indigenous Networks focused on Indigenous people tapping into European networks and working with Europeans, which, given the collection's emphasis on Indigenous participation in 'global networks of power', is understandable. By contrast, the contributors to this collection emphasise that, while Indigenous movement could be about global imperial and colonial networks, it could also be for purely Indigenous purposes: for community and individual economic wellbeing, to meet other Indigenous or non-Indigenous peoples and experience different cultures, to gather knowledge or experience desired within an Indigenous worldview and to escape from colonial intrusion. The essays presented here attempt to decentre, where possible, the role of Europeans within Indigenous travel; they emphasise Indigenous perspectives on, reasons for and agency in their own mobility. This involves looking at Indigenous communities - their arrangement of culture and economic and social contexts—as the primary locus of life.

29 Khatun 2015.

30 Carey and Lydon 2014: 1.

31 McDonnell 2015.

32 Carey and Lydon 2014: 1. 


\section{Analytic Possibilities of Scholarship on Indigenous Mobilities}

A focus on specific Indigenous communities as the locus of life assists authors to further question and unsettle the role of the nation within historical scholarship. Karen Fox, reflecting on trends in the writing of Indigenous histories in Australia and New Zealand, observed that 'transnational history seeks to move beyond the nation, looking across national borders, considering the importance of factors outside the nation and critiquing nationalist approaches to the past'. ${ }^{33}$ This issue of 'moving beyond' and 'looking across' nations has constituted both a promise and a problem in studies of historical mobility. Such studies have focused on the movement of Europeans and have assumed that a colonial or a 'national' border is defined by the non-Indigenous state. Consequently, the nation has both been problematised and, potentially, reinforced as the primary analytic category. Histories that trace and respect the continued production of Aboriginal geographies can help rally against scholarship that, even as it seeks to explain the processes of dispossession, can, as Khatun observed, 'replicate precisely the phenomenon they seek to critique: the erasure of Aboriginal geographies'. ${ }^{34}$

Indigenous geographies persist within settler colonial spaces in the form of Indigenous nations, language groups, tribal groups and iwi. These, of course, existed prior to the settler colonial state and they continue throughout colonial history into the present. Importantly, they continue to exist even when Indigenous people have been dispossessed from their territory. As Penny van Toorn asserted: 'New borders and boundaries don't necessarily supplant old ones. Australia is a palimpsest in which new and old borders and boundaries intersect and shift underfoot over time'. ${ }^{35}$ For Indigenous people, this provides a completely different meaning to the concept of border crossing in travel; to consider this is to bring a different dimension to the analysis of mobilities in settler colonial spaces-one that speaks to the importance of seeing Indigenous people travelling to other communities and across iwi, nation or language group borders as participating in cross-cultural encounters. As John Taylor and Martin Bell observed, 'migration' and 'diaspora' in the Indigenous sense generally

33 Fox 2012: 425.

34 Khatun 2015.

35 van Toorn 2010: 41. 
applies to movement within, rather than between, nation states. ${ }^{36}$ As such, mobility between Indigenous nations, language groups or other tribal formations should be seen as a form of migration that deserves the same recognition as international mobility. Analysing Indigenous mobility in Indigenous-centric ways has the potential to shed new light on wellworn historical explanations, and thus operates as an implicit challenge to history as a discipline.

Recognition of different boundaries to be crossed brings with it recognition of the political forms that underpin border crossings. Indigenous nations have their own polity, territory, unique social organisation and culture. To recognise these as the basis for different forms of movement is to recognise the different territories and polities that have created the borders. It is also to recognise that the category of the 'nation', so important to historical writing in the twentieth and twenty-first centuries, is imposed over the top of Indigenous political structures and territoriality. Further, it is to recognise that, while Indigenous forms are older, they are continuing, and that this continued presence tends to be ignored within the trajectories of histories of the nation. As Giselle Byrnes noted, the nation is not simply a remnant of 'nineteenth-century colonial ambition', it is 'a colonizing tool'; historiography that ignores Indigenous nations in their myriad and diverse forms effectively replicates the silencing and repression of Indigenous political systems. ${ }^{37}$ Paying attention to the different meanings, rituals and cultures of movement within Indigenous societies may provide a way to foreground Indigenous peoples and nations within history writing.

Focusing on Indigenous mobility forces us to interrogate colonial sources, asking questions about how they represent Indigenous people who travel. Indigenous people often come into historical sources when-and precisely because - they are mobile. Indigenous movement is captured in documents generated by those who utilised Aboriginal or Mãori mobility, such as explorers or ship's captains, or by those who displayed concern about their mobility, such as colonial officials, missionaries or protectors. Yet, within these sources, the motivations for, and meanings of, Indigenous mobilities are rarely fully understood or discussedor, indeed, even considered. Thus, the way we read these accounts is vital, for it determines how we understand Indigenous mobilities.

36 Bell and Taylor 2004: 263.

37 Byrnes 2009: 125. 
Rather than accepting the perspectives provided by European authors, determining Indigenous motivation and meaning involves searching for an Indigenous-centric interpretation. New work is helping to provide a model here. Through her careful reading of sources, Banivanua Mar's work on anti-colonial protest in Port Phillip, New Zealand and Tahiti exposed a 'counter-imperial and Indigenous circuitry' that developed out of fleeting physical contact between Indigenous peoples. ${ }^{38}$ Likewise, Lachy Paterson's close reading of Māori- and English-language sources provided new insights into the development of an 'imperial discourse of racial fraternity' between Māori and Indian troops who visited Australia and New Zealand. ${ }^{39}$ Ian Clarke and Fred Cahir's work on Māori visits to, and life in, Victoria also demonstrated the benefits of careful examination of extensive archival material. ${ }^{40}$

Closely examining issues of continuity and change between pre-colonial and colonial Indigenous mobility has the potential to problematise and complicate notions of European travel as well. Imperial and colonial agents often travelled along Indigenous routes, particularly (but not exclusively) in the early stages of settlement, guided by the knowledge of Indigenous peoples. ${ }^{41}$ In addition, Europeans often travelled according to Indigenous protocols, although they were not always aware of doing so. Paying close attention to routes, protocols and other forms of Indigenous knowledge complicates power relations that might otherwise be taken for granted, especially in cases where Indigenous people are said to be 'accompanying' Europeans. Indigenous mobility or travel was far more likely to be documented in the colonial archive when it involved Europeans. In reviewing such sources, it is important to consider whether the Europeans involved were being used by the Indigenous travellers as a means to an end-that is, as a way to facilitate travel. Mobility could take place for new or old reasons and could occur along new or old routes, and could be prompted by Indigenous-specific motivations, including cultural reasons or other reasons.

Consideration of the various motivations underlying Indigenous mobilities allows scholars to focus on Indigenous agency in multiple contexts, exploring how agency functions in racialised and highly

\footnotetext{
38 Banivanua Mar 2013.

39 Paterson 2013.

40 Cahir and Clark 2014.

41 Pratt 2007; Shellam, Nugent, Konishi and Cadzow 2016; Byrnes 2001.
} 
regulated environments. Scholarship in this volume considers the lure of the sea for Aboriginal people and Māori. Gopal Balachandran has shown how Indian seafarers, although they 'manned the world's ship', have 'languished as a historically invisible underclass'. ${ }^{42}$ Indian seafarers' lives were circumscribed and controlled by racialised policies and practices at every level, regulated in minute detail through 'routine bureaucratic agency' designed to render their presence invisible, even as their labour was central to world shipping. ${ }^{43}$ Janet Ewald's work has detailed racialised policies, such as the Asiatic Articles, that were applied to shipping labour and, importantly, the transformative possibilities of labouring on ships in the early nineteenth century. She observed:

Atlantic and Indian Ocean ports were sites for social transformations. Landsmen became seaman ... [b]ut seamen also became landsmen when sailors turned to port work between voyages. ${ }^{44}$

Slaves 'loosened or broke ties with their masters', making ships and port environments important places for possibility as well as restriction. ${ }^{45}$ Ewald's insights have been extended by Alison Bashford in her recent call for 'terraqueous' histories that attend to the connections and multiple meanings that diverse communities attribute to crossings between land and sea. ${ }^{46}$

In contrast to these restrictive and controlling regulations, Māori and Pacific Islander sailors, at least in the early years of Australian colonisation, were protected by a governor's order that stipulated they could only be removed from New Zealand with the consent of chiefs, and that masters of ships could not 'discharge any sailor or sailors, or other persons' in New Zealand without the 'permission of the chief or chiefs of the place'. ${ }^{47}$ The order was designed to protect trade interests and avoid the possibility of retaliation against shipping during a period in which Indigenous communities retained significant power, controlling access to resources and labour. Of course, racialised structures, policies and practices were still a factor for Aboriginal people and Māori when travelling on board ships; however, this example shows that the application of racialised forms of regulation was uneven, specific and not always designed to exploit

42 Balachandran 2012: 4, 10 .

43 Balachandran 2012: 10.

44 Ewald 2000: 73.

45 Ewald 2000: 73.

46 Bashford 2017: 261-62.

47 McNab 1908: 328-29. 
labour. Indeed, as Heather Goodall, Devleena Ghosh and Lindi Todd have shown, even with highly restrictive policies in place, individuals could slip between the cracks and subvert systems. They maintain that the presence of regulation in archival records is not evidence of the success of that regulation:

The official records, the catalogues and the schedules [that] European imperial powers were so well able to produce are actually the archives of mechanisms for control rather than proof that the controls worked ... we are looking at claims of achievement of the 'settler' goal, in which such documents are reflective of hopes, desires or fantasies rather than accomplished facts. ${ }^{48}$

As Russell argues in this volume, the sea offered a means of escape from land-based systems of surveillance and severe restrictions of movement for some Indigenous peoples. Attention to Indigenous mobilities offers the possibility of understanding agency in different land- and sea-based contexts, as well as the promise of a more nuanced understanding of how racial thought shaped policies of 'protection' and restriction.

\section{Aboriginal and Māori Cultures of Mobility}

We contend that Mãori and Aboriginal peoples undertook distinct forms of mobility in colonial history; each of the chapters in this volume attempts to elucidate these forms of travel. To delineate what is unique about Indigenous mobilities in imperial and colonial situations in the region, it is necessary to have a general understanding of the features of Aboriginal and Māori mobility. Taylor and Bell have called for 'sustained attention in ongoing research' to Indigenous mobilities. They maintain that:

A primary focus should be given to further elaborating the way in which mobility dynamics and settlement outcomes are shaped by the changing interface between Indigenous culture and the encapsulating state. An enhanced understanding of these interactions, in diverse settings and at varying temporal and spatial scales, is fundamental to articulation of a robust and comprehensive theory of mobility among Indigenous peoples. ${ }^{49}$

48 Goodall, Ghosh and Todd 2008: 47.

49 Bell and Taylor 2004: 263. 
Authors in this volume similarly argue that care must be taken to understand and account for Indigenous cultural forms and the effect they have on mobility.

Mobility is a vital feature of Indigenous Australian life. As Goodall and Cadzow have explained, 'mobility was and is as much a defining characteristic of Aboriginal cultures as affiliations with meaningful bounded places'. ${ }^{50}$ De Costa has argued that a 'mobility ethos' underpinned 'classical' Aboriginal society. Writing about Indigenous communities in terms of philosophies of diplomacy, de Costa asserted that cosmological ideas of 'interrelatedness and the connection of all things' shaped Indigenous communities, informing their embrace of 'mobility and its corollary of openness. ${ }^{51}$ Songlines and Dreaming narratives travel across regions; this means that neighbouring communities shared connections to particular stories. One group's 'authoritative reading' of a narrative does not preclude others having relationships to country or songlines. As de Costa explained, 'such connections give Indigenous peoples a context for engagement as well as reason to be mobile, to maintain their connections across different countries' ${ }^{52}$ In practical terms, mobility was, and is, required for ceremonial responsibilities tied to these cosmological narratives. Connections to common Dreaming narratives brought people together, often across large areas, to join for ceremonial purposes. An iconic and continuing ceremonial journey is that undertaken as part of Central Australian initiation practices:

According to customary practice, just prior to circumcision, boys were taken by their guardians on a journey to visit people in the region to gather them together for the actual ceremony. In the past this was done on foot over several months; today some initiation candidates, but not all, go off on a tour with their guardian using various forms of transport. ${ }^{53}$

As Peterson noted, in 1994, a journey undertaken prior to initiation of a young Western Desert man extended over 2,500 kilometres on the outward journey and gathered over 600 people for the ceremony. ${ }^{54}$

50 Goodall and Cadzow 2009: 21.

51 de Costa 2007: 16.

52 de Costa 2007: 15.

53 Peterson 2004: 230.

54 Peterson 2004: 230. 
As well as movement for ceremony, Indigenous Australians engaged in circular mobility in which people moved within their own country and wider region for economic, social and cultural reasons. Before colonisation, 'varying degrees of movement were required in pursuit of survival', and the extent of this movement was dependent on the nature of an Aboriginal nation's country. People living on resource-dense country engaged in 'highly localized movement', whereas desert people travelled over long distances. ${ }^{55}$ This regular and structured mobility in circular patterns formed 'functional regions' for Aboriginal people, which, in contemporary Australia, 'reflect persistence of the customary alongside change ${ }^{56}$ The movement around country for the purposes of food hunting and gathering followed seasonal patterns to exploit resource availability throughout the year. Jon Altman, in his fieldwork among eastern Kuninjku people in north-central Arnhem Land in 1979-80, followed the community's travel throughout their land over six distinct seasonsthree dry, three wet-as they harvested food and managed the land. ${ }^{57}$ Later work by Altman and Melinda Hinkson showed how Kuninjku's adoption of trucks facilitated movement back to country in the 1970s. The Kuninjku community saved considerable money to purchase vehicles to move back to country. The timing of these purchases allowed Kuninjku to reverse processes of centralisation of Aboriginal language groups in Maningrida in Arnhem Land, as it coincided with legislation for land rights, self-determination and financial assistance for the outstation movement. Kuninjku became highly engaged with the commercial arts market, developing an 'eclectic hybrid economy' that combined 'income from the state and earnings from arts production with a robust harvesting economy'. ${ }^{58}$ Kuninjku vehicles were used in accordance with Kuninjku values; the incorporation of trucks into the Kuninjku world reflected kinship structures, respect for seniority, gendered structures and avoidance relationships. ${ }^{59}$

Connection to sea country and waterways have also shaped mobility. Amanda Kearney and John Bradley investigated the relationship between modes of sea travel and Yanyuwa peoples' interactions with sea country. Hailing from the south-west Gulf of Carpentaria, Yanyuwa peoples

55 Peterson 2004: 223.

56 Taylor and Bell 2004b: 17.

57 Taylor and Bell 2004b: 18; Altman 1987.

58 Altman and Hinkson 2007: 188.

59 Altman and Hinkson 2007. 
derive their identity from being 'saltwater people'. ${ }^{60}$ Kearney and Bradley charted the changing technology that Yanyuwa used for journeys by sea and their shifting ideologies of movement as technology changed. They found that Yanyuwa embraced changing boat technology as Indigenous communities elsewhere embraced the car. They concluded that, unlike in non-Indigenous communities where cars are seen as instruments of autonomy', in Indigenous communities, boats and cars are tools 'for connecting, rather than disconnecting'; they are also ways to 'resist alienation'. ${ }^{61}$

According to Kearney and Bradley, elders who had witnessed the rise in the use of mechanised transport during their lifetime felt that 'really travelling' required walking, partly because the speed of mechanised transport jeopardised the unpredictable encounters between people and country that occurred during walking. ${ }^{62}$ Yet, conversely, the same technology applied to the sea resulted in new parts of sea country being opened up to Yanyuwa, and better and more regular access to the sea, including parts that colonial processes had severely curtailed. Noticing similar processes on rivers, Goodall and Cadzow observed that technologies for travel on rivers 'have changed and will continue to change'; however, this simply shows that 'mobility was and still is crucial in people's lives'. They argue that 'even land vehicles are still moving on routes shaped by the river valleys' ${ }^{63}$ Goodall and Cadzow demonstrated that the adoption of new technologies of movement to continue mobility for 'traditional' purposes is not simply a feature of remote Indigenous communities; instead, it operated and operates in Sydney too. However, it seems that these encounters were not that interesting to non-Indigenous people. As Victoria Haskins has explained with reference to Aboriginal people who embraced automobiles:

[It did] not capture white imaginations. It could not provide the same satisfaction as imagining the more mysterious people of the central and northern regions of Australia confronting the gleaming symbol of white man's modernity and technological prowess. ${ }^{64}$

60 Kearney and Bradley 2015.

61 Kearney and Bradley 2015: 174.

62 Kearney and Bradley 2015: 174.

63 Goodall and Cadzow 2009: 21.

64 Haskins 2008: 72. 
Mobility is a feature of Aboriginal social life. Aboriginal people travel to maintain connections with kin. Such movement is not confined to rural and remote Australia. It is a feature of the lives of urban Aboriginal people in both contemporary and historical settings. Aboriginal people from early in colonial history have travelled between new residences and their home country. As Taylor and Bell have observed:

From the early stages of urbanization, Indigenous people sought to maintain links between their new residential bases and family in the hinterland from which they were drawn. This was accomplished by engaging in frequent mobility between the two. ${ }^{65}$

It should be emphasised that urban sites are also Indigenous country; it is not only the 'hinterland' that is Indigenous.

In Aboriginal life, both mobility and fixedness play important roles in a person's identity. Peterson explained how 'mobility is fundamental to an Aboriginal individual's social identity', as networks and relationshipshence shared identity-are renewed through travel. Travel also offers personal autonomy, as people move to escape the control or direction of others. Yet fixedness was also crucial: 'relationships to place and country were central to Aboriginal political identity', as community and personal identity is drawn from relationships to specific areas of land.$^{66}$ Hence, coming back to one's own country and returning to place were vital parts of travel. These two aspects of Aboriginal cultural life are encapsulated in the importance accorded to boundary-crossing protocols. As Turnbull observed:

Australian Aboriginal groups had a highly articulated understanding of their own territory and kinship and had a well developed form of social organisation reflected in boundary practices and protocols governing the ways authority and ownership should be acknowledged and how permission should be sought and granted. This systems of norms and signs that made negotiated boundary-crossing permissions possible reveals a politics and territorial distribution and also provides the conditions for the possibility of trust and the movement of knowledge along networks or 'strings' of connectedness. ${ }^{67}$

65 Taylor and Bell 2004b: 20.

66 Peterson 2004: 224.

67 Turnbull 2004: 175. 
Mobility was, and is, of fundamental importance to Mãori culture and life as well. It was, and is, central to the identity of individuals and communities; the arrival of waka (traditional Māori canoes) after long sea-journeys from Hawaiiki features in the foundation stories of iwi (Māori tribes) across the country. Oral histories of ancestral journeys of exploration by land and sea explain a community's journey of arrival as well as their claims to tribal lands. ${ }^{68}$

Mobility remained important in everyday life in the pre-colonial period. People travelled for a range of purposes: to visit family, to harvest food, to trade for both food and objects of material culture and to engage in war. ${ }^{69}$ Māori society has been described as 'highly mobile' during the 'early pre-contact period'. According to Manahuia Barcham, mobility increased during the 'classical' period of Māori history, 'as endemic warfare, due in large part to a shrinking resource base especially in terms of food (particularly meat), led these groups to engage in increased levels of warfare and conquest'. ${ }^{70}$ The Käi Tahu groups that moved from the east coast of the North Island in the eighteenth century, marrying into and also defeating other communities as they moved south, eventually coming to establish their territory throughout most of the South Island, show how mobility shaped the histories of communities. ${ }^{71}$ Mobility was vital to Kāi Tahu's pre-colonial life, as Michael Stevens' chapter in this collection describes, with people moving into the south and then continuing to travel seasonally to take advantage of food resources, including extended stays offshore to carry out the annual tîtī (sooty shearwater or mutton-bird) harvest. ${ }^{72}$ The birds, preserved and packed for long-term storage, were traded over long distances to communities in the north. This communityspecific movement of both people and goods remains central to Kāi Tahu culture and identity today.

These already high levels of Māori mobility escalated after initial contact with Europeans. There was an intensification of 'warfare-induced mobility' as muskets were introduced to New Zealand by Europeans. ${ }^{73}$ As Barcham observed:

68 Taonui n.d.

69 Ballantyne 2011: 63 .

70 Barcham 2004: 163.

71 Anderson 1998: 57-62.

72 Stevens 2006.

73 Barcham 2004: 163. 
The period of the early nineteenth century was thus characterized by extremely high levels of mobility for Māori as large numbers of people were displaced as they attempted to escape the various conflicts that raged over the country during this period. ${ }^{74}$

Many people moved by choice to exploit new opportunities for knowledge, goods or contacts that developed around centres where Europeans congregated; the forcible movement of slaves also occurred..$^{75}$ As chapters in this volume demonstrate, the early nineteenth century saw Māori exploit opportunities to travel overseas; Port Jackson became an important destination for Māori travel, as well as a transit point for travel further afield. This international migration has remained a feature of Māori life, placing 'Māori somewhat at odds with other Indigenous populations', as Taylor and Bell have noted (although other Pacific peoples may also have high levels of overseas migration) ${ }^{76}$ Ian Pool concluded that:

It is possible that the migrations of the early nineteenth century far exceeded mobility in previous periods, and may have been more important proportionally than subsequent inter regional movements until rapid urbanisation occurred after World War II. ${ }^{77}$

Colonisation from 1840 brought changes that significantly reduced Māori mobility as land was alienated swiftly in comparison to many areas of Australia. Moreover, there were other political implications of colonisation, as Ballantyne established:

The consolidation of British rule not only reduced Māori mobility but also calcified takiwā and rohe [boundaries] ... Under colonial rule tribal boundaries that had only taken shape in the previous couple of decades were now seen as durable and 'traditional'. ${ }^{78}$

Reduced mobility during the colonial period did not mean that Māori were not mobile during this period, as contributions in this volume by Lachy Paterson, Angela Wanhalla and Michael Stevens attest.

\footnotetext{
74 Barcham 2004: 163-64.

75 Ballantyne 2011: 64.

76 Taylor and Bell 2004a: 6.

77 Pool 2013.

78 Ballantyne 2011: 64 .
} 


\section{The Politics of Aboriginal and Māori Mobility}

Not only were Aboriginal and Māori mobilities different in form and nature, and specific to the cultural, economic and social lives of particular communities, they were read and reacted to differently within imperial and colonial situations. Māori, as outlined above, were noted for having engaged in international travel, using the arrival of European ships in their waters as an opportunity to travel to New South Wales and further afield from the early nineteenth century. The early journeys were often made by young men of chiefly status, although, as Wanhalla discusses here, this was not exclusively the case, as women also crossed the Tasman Sea. The social position of the travellers, combined with British interest in observing a new culture, meant that visiting Māori excited considerable interest in New South Wales. They were often met and entertained by colonial officials, including governors, leading to the view that such visits were 'diplomatic relations' ${ }^{79}$ According to British colonists, these international travellers showed appropriate respect, interest and capacity for improvement in making the journey to investigate British society in the region. What, to colonists in New South Wales, seemed a recognition of British superiority and a curiosity about technology and civilisation was, for Māori, a chance to gain advantages at home for the benefit of their communities. The relationships forged and knowledge developed during those visits to Australia also opened up resources in New Zealand for the British-resources that could be accessed with the permission of chiefs, with Māori labour and, it was assumed, without conflict. At this time, Māori and Pacific peoples' labour on ships was becoming an important part of the region's workforce, and this form of mobility led to efforts at 'protection' by the New South Wales colonial government, as it was keen to prevent mistreatment that could jeopardise access to resources or lead to violent conflict. ${ }^{80}$

Regina Ganter's contribution here documents northern Aboriginal international travel and engagement-forms of Indigenous mobility that have not informed racial discourses due to their northern focus and their connections forged to Asian, rather than European, communities. The absence of such journeys from Australian historiography has resulted in the concomitant absence of representations of Aboriginal people as

79 Salmond 1997.

80 Standfield 2012: Chapter 1. 
curious or interested in improvement. By contrast, the international travel that Māori undertook during the contact period (and have undertaken in a sustained way ever since), produced a particular view of Māori that, as several chapters in this volume argue, influenced New Zealand's imperial history and histories of the region. Many Māori have also been involved in internal migration, moving from rural to urban environments. Melissa Matutina Williams has explored Panguru migration from Hokianga to Auckland during the mid-twentieth century, a migration that was part of her own family history. Her oral histories retain a tribal focus because, as she explained:

The people who migrated out of Panguru did not migrate out of their whakapapa and, by extension, their connection to the whenua. Tribal connections were not cut by geographical space, state policy or academic theory. You remain part of a tribal story regardless of where you live or the degree of knowledge or interaction you may have with your whanaunga and tribal homeland. ${ }^{81}$

Challenging the idea that migration necessarily produces emotions of loss and isolation, Nepia Mahuika showed that such assumptions are complicated by inter-iwi connections-engagement between those migrating and the people of Auckland, Wellington or other New Zealand cities-as well as the connections that many migrants continue to foster with their whānau (family) and iwi at home. Unproblematic depictions of loss or dislocation fail to account for mātauranga Māori (Māori knowledge) and related creation narratives, rooted in land, through which iwi share connection to New Zealand geographies. As well as tribal identities, historians must be cognisant of the identification that many people have to being 'Māori'. ${ }^{82}$ This is not to say that migrants did not experience feelings of isolation or loss, but that these were caused by more complex processes than moving to an urban location. ${ }^{83}$

Significant meaning has been accorded to Aboriginal mobility in the Australian colonial context. Aboriginal movement has been highly politicised, racialised and used as a justification for colonisation. From the outset of colonisation, Aboriginal movement was viewed as 'wandering'that is, as taking a form that precluded land ownership. David Turnbull characterised wandering as 'the first-order descriptor invoked whenever

81 Williams 2015: 28.

82 Mahuika 2009.

83 Mahuika 2009: 140. 
indigenes are described ... implying a timeless, placeless, and directionless existence'.$^{84}$ He argued that land, to be seen as 'empty', did not have to be free of inhabitants; it was sufficient to have inhabitants who were seen as 'wanderers with no complex organisation or laws'. ${ }^{85}$ To be deemed as wanderers rendered an Indigenous population as placeless in the eyes of European colonisers:

Having no place meant no organization, no law, no labor, no cultivation, no property, no boundaries. All of which were essential components of enlightenment rationality and the complete antithesis of wandering, revealing both the profoundly place-based, static and boundaried spatial ontology underpinning modern rationality and epistemology and the profound tension in which it was constituted. ${ }^{86}$

Aboriginal movement through country-the ordered, regular, seasonal circular mobility that was highly attuned to the landscape-was characterised as irrational and read as being antithetical to Indigenous rights in land. These views had powerful effects on Aboriginal people, underpinning government and legal discussions that ignored Aboriginal sovereignty and land ownership and justified the appropriation of land for European uses. These ideas continue to hold great power, for while the legal basis of the concept of terra nullius has been overturned, Indigenous authors have stressed that a psychological terra nullius continues unabated within Australian society. ${ }^{87}$

The serious negative connotations associated with Aboriginal movement created a focus in colonial policies on restricting movement. The 'problem' of Indigenous mobility, as Australian colonial authorities envisioned it, meant that policies and practices focused on regulating Indigenous movement loomed large in the tactics undertaken by government. These involved restrictions on movement over country, policies of forced movement in which populations were shifted off country and on to reserves, and ongoing policies of removing Indigenous children from families - all carried out in the name of civilisation: to 'settle' Aboriginal people. Such policies had practical benefits for colonial

84 Turnbull 2004: 175 .

85 Turnbull 2004: 175 .

86 Turnbull 2004: 175.

87 Behrendt 2003: 3. Senator Aiden Ridgeway described this in 2001 as a terra nullius of the mind'. See Standfield 2004. 
society; they helped curtail Aboriginal physical resistance and removed Aboriginal people from country, making additional areas of land available for colonial occupation.

These readings of Australian Aboriginal mobility are not confined to the early period of colonial history; they continued to shape views of Aboriginal people throughout the twentieth century and they persist into the present. As Peterson has observed, the idea of Aboriginal people going 'walkabout' is 'one of the most mythological aspects of Australian Aboriginal behaviour'. ${ }^{88}$ Walkabout is 'usually understood in terms of some urge that results in Aboriginal people leaving a locality without notice to travel for travel's sake'. ${ }^{89}$ This idea has such power that Aboriginal people are seen as a 'walkabout race'. According to Sarah Prout, notions of unpredictable Aboriginal movement shape non-Indigenous interactions with Aboriginal people in the context of service provision in Western Australia. ${ }^{90}$ The trope of Aboriginal people as wandering has been powerful, and consistent, throughout Australian colonial history. ${ }^{91}$ In fact, Ann Curthoys has argued that the idea of Indigenous people as fixed and local does not apply to Aboriginal people, as 'the idea of Aboriginal people as nomads with no attachment or claim to the land was far more prominent in settler discourse'. ${ }^{92}$

Movement is not only an important factor in Aboriginal culture and identity; it has proved to be vitally important in resisting colonial incursions and restrictions on movement. Peterson has described 'walkabout' as:

An everyday form of resistance: Aboriginal people avoided letting employers know they intended leaving because they denied their employers' right to control their lives. Further, the employers' assumption that the urge to leave was biologically based helped reproduce unheralded departures because such an assumption meant that people were rarely called on to account for their movements. ${ }^{93}$

90 Prout 2009.

91 See, for example, Karen Fox's discussion of the concept of walkabout being applied to Yvonne Gollagong's tennis performances to explain occasional lapses of concentration. Fox 2011: 57-59.

92 Carey and Lydon 2014: 9.

93 Peterson 2004: 223. 
Denis Byrne analysed the way that Aboriginal people subverted the cadastral grid laid by colonisers as they took over new areas of land in Australia from 1788. Mobility was key to Aboriginal people maintaining relationships to country, even when land was no longer easily available to them, as it was 'owned' by others. As Byrne explained, Aboriginal people negotiated "moving through the "openings" between the private properties of the cadastral grid', developing 'a web of tactical relationships with those white landowners prepared to be friendly or, at least, not to be hostile. ${ }^{94}$ Similar processes occurred in New Zealand; where access to mahinga kai (food gathering places) was closed off to Māori, negotiation of the cadastral grid became necessary.

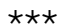

The antipodean theme and the comparisons drawn in our volume grow out of relationships between the contributing authors, and between the authors and their own mobility. The volume reflects the commitment of those authors to take their scholarship beyond national borders, strengthening their work by understanding what is common and what is unique in comparison to other histories in the region. The contributors demonstrate that engagement with Indigenous social, cultural and political organisation can enable understanding of the specific and ontologically and epistemologically driven mobilities of Indigenous communities. Chapters by Konishi, Shellam, Wanhalla, Standfield, Ganter and Stevens focus on the specific culturally imbued meanings of movement. Chapters by Konishi, Shellam and Wanhalla are sensitive to travel between distinct Indigenous nations or tribal areas. Konishi explores evidence for Aboriginal boundary-crossing rituals in early European exploration journals, demonstrating how European exploration accounts can help us to understand pre-colonial Aboriginal mobility, rituals of negotiated boundary crossing and the vital role played by Aboriginal intermediaries in European exploration. Shellam investigates the travels of Miago, a Nyungar man from south-west Western Australia, and considers the cultural knowledge of the new Aboriginal communities he developed on his journeys. Wanhalla explores the international and local mobility of two Indigenous women - a Canadian Aboriginal woman and a Käi Tahu woman—and considers their parallel lives spent living on, and adjacent

94 Byrne 2010: 113-14. 
to, the Taieri Native Reserve in New Zealand's South Island. Russell reads Aboriginal travel in the colonial period as an extension of pre-colonial mobility, as does Stevens in regard to his own Kāi Tahu people.

The volume demonstrates the limitations of language to explain the complexity of histories of Indigenous mobilities. Chapters expressly interrogate the often implicit assumptions of scholars that Indigenous peoples are wholly 'grounded' in their land, fixed either through attachment to country or through colonial control in which policies of colonial containment are assumed to be wholly successful in stopping Indigenous movement. The weight of these assumptions, combined with the drive to homogeneity that blanket categories of 'Indigenous' tend to encourage, can make even recognising Indigenous movement a difficult undertaking. Through careful empirical work, chapters here interrogate these tropes of indigeneity and bring to light the complex experiences and histories of Indigenous individuals and groups. Cognisant of Indigenous agency and its limitations, authors display awareness of culturally driven travel; Indigenous people who grasped opportunities for travel opened up by imperial and colonial associations; and, conversely, of the colonial situations that restricted Indigenous movement or forced (or coerced) travel. Both Russell and Harman focus on the mobility of Tasmanian Aboriginal people in the nineteenth century, investigating how Aboriginal people reacted to restraints placed on their movement and their creative exploitation of opportunities for movement. Harman explores the constrained mobility of Aboriginal people living at the Oyster Cove settlement, highlighting their agency in grasping opportunitiessanctioned by colonial officials or not-to maintain mobile lifestyles. Russell documents the mobility of Tasmanian Aboriginal people within colonial coastal industries, considering these new opportunities as extensions of 'traditional' Aboriginal mobilities. Her chapter shows how opportunities to work on ships, even within racially structured shipping environments, offered an escape from the containment and surveillance of land-based colonial regimes.

The collection aims to decentre the role of Europeans by undermining assumptions that Europeans were always central to Indigenous travel. Chapters by Paterson and Ganter explore Indigenous and non-European encounters through travel. While Paterson explores Māori-Rarotongan contact, Ganter probes the effects of Aboriginal encounters with Asian communities on Aboriginal identities and cultural values. Several chapters examine early Aboriginal and Māori travel. Taking a long-run view, 
chapters by Paterson and Stevens examine the ongoing movement of Kāi Tahu and Ngāti Whātua people respectively, looking at their established connections with particular peoples and places, and examining how specific destinations have shaped these communities. Ganter too investigates the re-establishing of connections after sustained periods of government control that quashed long-established trade connections.

Two chapters take mobilities further than the usual focus on people, exploring the movement of objects and ideas that travelled with Indigenous people. Curthoys and Lake emphasised that transnational history 'seeks to understand ideas, things, people and practices [that] have crossed national boundaries'. ${ }^{95}$ However, as Ballantyne has argued, by seeing the British as 'unfettered and unchanged' by Indigenous peoples, new imperial history has failed to account for Indigenous experience. ${ }^{96}$ For Indigenous mobilities to be truly integrated into mobilities scholarship, Indigenous goods, practices and values must be understood as affective- that is, as capable of influencing encounters and relationships between Indigenous and non-Indigenous people, mirroring the way that Europeans' goods, practices and values are assumed to have affected Indigenous people. Ballantyne's offering in this volume explores how mobility shaped early printed texts in New Zealand and how these texts were, themselves, mobile, opening up new forms of knowledge and being imbued with different meanings as they travelled through Māori communities. Standfield's chapter follows the movement of both people and ideas between New Zealand and Port Jackson in the early nineteenth century, arguing that Māori values of reciprocity in relationships shaped the reception of missionaries in New Zealand, and that the mobility of Indigenous values and ideas is a vital aspect of cross-cultural contact that has the power to influence imperial activity.

Overall, this volume hopes to contribute to a developing field of scholarship on Indigenous mobilities in which Indigenous people and communities are recognised and respected as distinct; as having their own motivations for travelling, and for living their cultures while travelling; as crossing boundaries other than those imposed by Europeans; as expressing boundary-crossing protocols; and as undertaking shorter journeys that 
might have as much significance as travelling the globe. In short, we hope that Indigenous people can emerge from the archives as active voyagers recognised in histories as expressing their own ambitions and agency.

\section{References}

Altman, Jon 1987, Hunter-Gatherers Today: An Aboriginal Economy in North Australia, Australian Institute of Aboriginal Studies, Canberra.

Altman, Jon and Melinda Hinkson 2007, 'Mobility and modernity in Arnhem Land: The social universe of Kuninjku trucks', Journal of MaterialCulture12(2):181-203.doi.org/10.1177/1359183507078122

Anderson, Atholl 1998, The Welcome of Strangers: An Ethnohistory of Southern Maori AD 1650-1850, University of Otago Press, Dunedin.

Balachandran, Gopal 2012, Globalizing Labour? Indian Seafarers and World Shipping, c. 1879-1945, Oxford University Press, New Delhi.

Ballantyne, Tony 2002, Orientalism and Race: Aryanism in the British Empire, Palgrave, Bassingstoke, New York. doi.org/10.1057/ 9780230508071

Ballantyne, Tony 2010, 'The changing shape of the modern British Empire and its historiography', The Historical Journal 55(2): 429-52. doi.org/10.1017/S0018246X10000117

Ballantyne, Tony 2011, 'On place, space and mobility in nineteenth century New Zealand', New Zealand Journal of History 45(1): 50-70.

Ballantyne, Tony 2014, Entanglements of Empire: Missionaries, Maori and the Question of the Body, Duke University Press, Durham. doi.org/ $10.1215 / 9780822375883$

Ballantyne, Tony and Antoinette Burton 2009, 'Introduction: The politics of intimacy in an age of empire', in Moving Subjects: Gender, Mobility, and Intimacy in an Age of Global Empire, Tony Ballantyne and Antoinette Burton (eds), University of Illinois Press, Urbana: 1-28.

Banivanua Mar, Tracey 2013, 'Imperial literacy and Indigenous rights: Tracing transoceanic circuits of a modern discourse', Aboriginal History (37): 1-28. 
Barcham, Manahuia 2004, 'The politics of Maori mobility', in Population Mobility and Indigenous Peoples in Australasia and North America, John Taylor and Martin Bell (eds), Routledge, London and New York: 163-83.

Bashford, Alison 2017, 'Terraqueous histories', The Historical Journal 60(2): 253-72. doi.org/10.1017/S0018246X16000431

Behrendt, Larissa 2003, Achieving Social Justice: Indigenous Rights and Australia's Future, The Federation Press, Sydney.

Bell, Martin and John Taylor 2004, 'Conclusion: Emerging research themes' in Population Mobility and Indigenous Peoples in Australasia and North America, John Taylor and Martin Bell (eds), Routledge, London and New York: 262-67.

Binney, Judith 2004, 'Tuki's universe', New Zealand Journal of History 38(2): 215-32.

Byrne, Denis 2010, 'Nervous landscapes: Race and space in Australia', in Making Settler Colonial Space: Perspectives on Race, Place and Identity, Tracey Banivanua Mar and Penelope Edmonds (eds), Palgrave Macmillan, Houndsmill and New York: 103-28. doi.org/10.1057/ 9780230277946_8

Byrnes, Giselle 2001, Boundary Markers: Land Surveying and the Colonisation of New Zealand, Bridget Williams Books, Wellington. doi.org/10.7810/9781877242908

Byrnes, Giselle 2009, 'Nation and migration', New Zealand Journal of History 43(2): 123-32.

Cahir, Fred and Ian D. Clark 2014, 'The Maori presence in Victoria, Australia, 1830-1900: A preliminary analysis of Australian sources', New Zealand Journal of History 48(1): 109-26.

Carey, Jane and Jane Lydon 2014, 'Introduction: Indigenous networks, historical trajectories and contemporary connections', in Indigenous Networks: Mobility, Connections and Exchange, Jane Lydon and Jane Carey (eds), Routledge, New York: 1-26.

Clarsen, Georgine 2008, Eat My Dust: Early Women Motorists, Johns Hopkins University Press, Baltimore. 
Clarsen, Georgine 2011, 'The flip side: Women on the redex around Australia reliability trials of the 1950s', Humanities Research 17(2): $17-36$.

Curthoys, Ann 2003, 'We've just started making national histories, and you want us to stop already?', in After the Imperial Turn: Thinking With and Through the Nation, Antoinette Burton (ed.), Duke University Press, Durham: 70-89.

Curthoys, Ann and Marilyn Lake (eds) 2005, Connected Worlds: History in Transnational Perspective, ANU E Press, Canberra.

David, Frank, Leah Lui-Chivizhe and Jude Philip 2015, 'Individuals in Kulkalgal history', Journal of Australian Studies 39(3): 290-306. doi.org/10.1080/14443058.2015.1051086

Deacon, Desley, Penny Russell and Angela Woollacott (eds) 2010, Transnational Lives: Biographies of Global Modernity, 1700-Present, Palgrave Macmillan, Bassingstoke, New York.

de Costa, Ravi 2006, A Higher Authority: Indigenous Transnationalism and Australia, UNSW Press, Sydney.

de Costa, Ravi 2007, 'Cosmology, mobility and exchange: Indigenous diplomacies before the nation-state', Canadian Foreign Policy 13(3): 13-28. doi.org/10.1080/11926422.2007.9673440

Deloria, Philip J. 2004, 'Technology: I want to ride in Geronimo's Cadillac', in his Indians in Unexpected Places, University Press of Kansas, Lawrence: 136-82.

Elbourne, Elizabeth 2005, 'Indigenous peoples and imperial networks in the early nineteenth century: The politics of knowledge', in Rediscovering the British World, Phillip Buckner and R. Douglas Francis (eds), University of Calgary Press, Calgary: 59-85.

Ewald, Janet J. 2000, 'Crossers of the sea: Slaves, freedmen, and other migrants in the northwestern Indian Ocean, c. 1750-1914', The American Historical Review 105(1): 69-91.

Fox, Karen 2011, Maori and Aboriginal Women in the Public Eye: Representing Difference, 1950-2000, ANU E Press, Canberra. 
Fox, Karen 2012, 'Globalising indigeneity? Writing Indigenous histories in a transnational world', History Compass 10(6): 423-39. doi.org/ 10.1111/j.1478-0542.2012.00855.x

Goodall, Heather and Allison Cadzow 2009, Rivers and Resilience: Aboriginal People on Sydney's Georges River, UNSW Press, Sydney.

Goodall, Heather, Devleena Ghosh and Lindi R. Todd 2008, 'Jumping ship—skirting empire: Indians, Aborigines and Australians across the Indian Ocean', Transforming Cultures eJournal 3(1): 44-74.

Haskins, Victoria 2008, 'The smoking buggy', in Off the Beaten Track: A Journey Across the Nation, Alison Russell (ed.), National Motor Museum, Birdwood: 72-81.

Hau'ofa, Epeli 1993, 'Our sea of islands', in A New Oceania: Rediscovering Our Sea of Islands, Eric Waddell, Vijay Naidu, and Epeli Hau'ofa (eds), School of Social and Economic Development, University of the South Pacific and Bleake House, Suva: 2-16.

Jones, Alison and Kuni Jenkins 2011, He Körero-Words Between Us: First Mãori-Päkehā Conversations on Paper, Huia Publications, Auckland.

Kearney, Amanda and John J. Bradley 2015, 'When a long way in a bark canoe is a quick trip in a boat', Quaternary International 385: 166-76. doi.org/10.1016/j.quaint.2014.07.004

Khatun, Samia 2015, 'Beyond blank spaces: Five tracks to late-nineteenth century Beltana', Transfers 5(3): 68-86.

Lambert, David and Alan Lester (eds) 2006, Colonial Lives Across the British Empire, Cambridge University Press, Cambridge.

Lester, Alan 2001, Imperial Networks: Creating Identities in Nineteenth Century South Africa and Britain, Routledge, London and New York.

Lester, Alan and Zoe Laidlaw 2015, 'Indigenous sites and mobilities: Connected sites in the long nineteenth century', in Indigenous Communities and Settler Colonialism: Land Holding, Loss and Survival and an Interconnected World, Zoe Laidlaw and Alan Lester (eds), Palgrave Macmillan, London: 1-23. doi.org/10.1057/9781137452368_1

Mahuika, Nepia 2009, 'Revitalizing Te Ika-a-Maui: Māori migration and the nation', New Zealand Journal of History 43(2): 133-49. 
Maynard, John 2005, "In the interests of our people": The influence of Garveyism on the rise of Australian Aboriginal political activism', Aboriginal History 29: 1-22.

McDonnell, Michael A. 2015, 'Indigenous networks: Mobility, connections and exchange', Australian Historical Studies 46(2): 312-13. doi.org/10.1080/1031461X.2015.1040580

McNab, Robert (ed.) 1908, Historical Records of New Zealand, Volume 1, Government Printer. Wellington, www.enzb.auckland.ac.nz/document? wid $=3870 \&$ page $=0 \&$ action $=$ null

Paisley, Fiona 2004, "Performing New Zealand": Maori and Pakeha delegates at the pan-Pacific women's conference, Hawai' $i$, 1934', New Zealand Journal of History 38(1): 22-38.

Paisley, Fiona 2006, 'Glamour in the Pacific: Cultural internationalism and Maori politics at pan-Pacific women's conferences in the 1950s', Pacific Studies 29(1): 54-81.

Paisley, Fiona 2012, The Lone Protestor: AM Fernando in Australia and Europe, Aboriginal Studies Press, Canberra.

Paterson, Lachy 2013, 'The similarity of hue constituted no special bond of intimacy between them', Journal of New Zealand Studies 14: 19-40.

Peterson, Nicolas 2004, 'Myth of the "walkabout": Movement in the Aboriginal domain', in Population Mobility and Indigenous Peoples in Australasia and North America, John Taylor and Martin Bell (eds), Routledge, London and New York: 223-38.

Pool, Ian 2013, Te Iwi Maori: Population Past, Present and Projected, Auckland University Press, Auckland.

Pratt, Mary Louise 2007, Imperial Eyes: Travel Writing and Transculturation, Routledge, London, New York.

Prout, Sarah 2009, 'Security and belonging: Reconceptualising Aboriginal spatial mobilities in Yamatji country, Western Australia', Mobilities 4(2): 177-202. doi.org/10.1080/17450100902905105

Russell, Lynette 2008, “A New Holland half-caste”: Sealer and whaler Tommy Chaseland', History Australia 5(1): 08.1-08.15. 
Russell, Lynette 2012, Roving Mariners: Australian Aboriginal Whalers and Sealers in the Southern Oceans, 1790-1870, State University of New York Press, Albany.

Russell, Penny, Desley Deacon and Angela Woollacott 2008, Transnational Ties: Australian Lives in the World, ANU E Press, Canberra.

Salmond, Anne 1997, Between Worlds: Early Exchanges between Maori and Europeans, 1773-1815, Viking Press, Auckland.

Shellam, Tiffany, Maria Nugent, Shino Konishi and Alison Cadzow 2016, Brokers and Boundaries. Colonial Exploration in Indigenous Territory, ANU Press, Canberra. doi.org/10.22459/BB.04.2016

Standfield, Rachel 2004, 'A remarkably tolerant nation? Constructions of benign whiteness in Australian political discourse', Borderlands e-journal 3(2).

Standfield, Rachel 2012, Race and Identity in the Tasman World, 17691840, Pickering and Chatto, London.

Stevens, Michael J. 2006, 'Kāi Tahu me te Hopu Tìtī ki Rakiura: An exception to the "colonial rule"?', Journal of Pacific History 41(3): 273-91. doi.org/10.1080/00223340600984737

Taonui, Rāwiri n.d., 'Ngā Waewae tapu-Māori exploration', Te AraThe Encyclopaedia of New Zealand, teara.govt.nz/en/nga-waewae-tapumaori-exploration

Taylor, John and Martin Bell 2004a, 'Introduction: New world demography', in Population Mobility and Indigenous Peoples in Australasia and North America, John Taylor and Martin Bell (eds), Routledge, London and New York: 1-10.

Taylor, John and Martin Bell 2004b, 'Continuity and change in Indigenous Australian population mobility', in Population Mobility and Indigenous Peoples in Australasia and North America, John Taylor and Martin Bell (eds), Routledge, London and New York: 13-43.

Turnbull, David 2004, 'Narrative traditions of space, time and trust in court: Terra nullius, "wandering", the Yorta Yorta native title claim, and the Hindmarsh Island bridge controversy', in Expertise in Regulation and Law, Gary Edmond (ed.), Aldershot and Burlington, Ashgate: 166-83. 
van Toorn, Penny 2010, 'Writing the entrapped nations of Indigenous Australia into being', in Transnational Lives: Biographies on Global Modernity, 1700-present, Penny Russell, Desley Deacon and Angela Woollacott (eds), Palgrave Macmillan, Houndmills, Basingstoke: 41-53. doi.org/10.1057/9780230277472_4

Williams, Melissa Matutina 2015, Panguru and the City: Käinga Tahi, Käinga Rua: An Urban Migration History, Bridget Williams Books, Wellington. 
This text is taken from Indigenous Mobilities: Across and Beyond the Antipodes, edited by Rachel Standfield, published 2018 by ANU Press, The Australian National University, Canberra, Australia.

doi.org/10.22459/IM.06.2018.01 